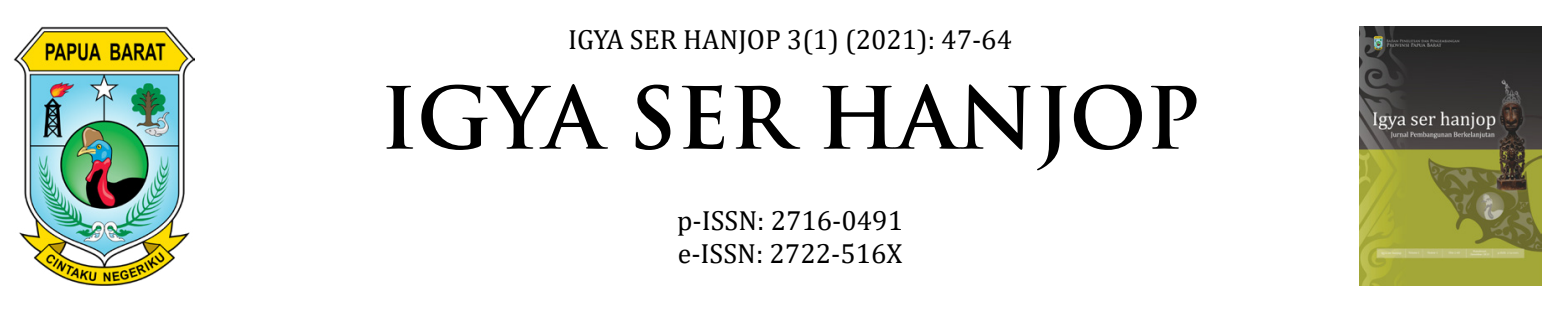

\title{
Pengaruh Perubahan Fungsi Hutan terhadap Keanekaragaman Katak: Studi KaSUS di Prafi, DisTRIK PRAFI, KabUPATEN MANOKWARI
}

\section{THE IMPACT OF CHANGING OF FoREST FUnCTIONS on Frog Diversity: a CASE STUdy FRom PRAFi District, MANOKWARI REGENCY}

\author{
Keliopas Krey ${ }^{1}$, Amaul Nur Apsyari' ${ }^{2}$, Yance de Fretes ${ }^{3 *}$ \\ ${ }^{1,2,3}$ Fakultas Matematika dan Ilmu Pengetahuan Alam, Universitas Papua \\ Jl. Gunung Salju Amban, Manokwari, Papua Barat 98314
}

Dikirim: 22 April 2021; Disetujui: 20 Mei 2021; Diterbitkan: 20 Juni 2021

DOI: 10.47039/ish.3.2021.47-64

\begin{abstract}
Inti Sari
Hutan tropis dataran rendah diketahui merupakan habitat penting bagi berbagai spesies flora dan fauna. Hutan tropis juga berperan penting untuk menjaga fungsi hidrologis dan saat diketahui memilih fungsi penting dalam menjaga gas rumah kaca, salah satu penyebab perubahan iklim global. Namun, hutan tropis banyak telah konversi ke berbagai fungsi non hutan, seperti perkebunan komersial. Sebagai negara tropis, Indonesia memiliki hutan tropis terluas kedua di dunia. Walaupun pemerintah dan penggiat konservasi telah berusaha untuk menjaga perubahan fungsi hutan, tetapi perubahan fungsi hutan terus terjadi sejalan dengan pertambahan penduduk dan kebutuhan pembagunan. Penelitian ini dirancang untuk meneliti dampak perubahan fungsi hutan ke non hutan terhadap keragaman katak di Distrik Prafi, Kabupaten Manokwari. Membandingkan keragaman katak pada 3 fungsi hutan: hutan sekunder, perkebunan sawit dan perkebunan kakao. Hasil penelitian ini menunjukkan konservasi hutan ke non hutan memberikan dampak negatif terhadap keragaman katak. Konversi hutan juga memberikan kesempatan pada spesies yang diintroduksi seperti Duttaphrynus melanostictus, Fejervarya cancrivora dan F. limnocharis hidup dan mendominasi habitat baru ini. Suatu hal menarik adalah bahwa tidak ada satupun spesies asli Papua yang dapat diamati di perkebunan, walaupun perubahan atau konversi hutan telah terjadi sekitar 40 tahun lalu. Penelitian ini juga memastikan kehadiran spesies introduksi baru F. limnocharis di Prafi. Spesies ini mungkin dimasukkan secara tidak sengaja ke Tanah Papua.
\end{abstract}

Kata Kunci: keragaman katak, dampak perubahan fungsi hutan, Distrik Prafi.

\section{Abstract}

Tropical lowland rainforests are known to harbor number of flora and fauna species. Tropical lowland rainforest plays important roles to maintain hydrological functions and lately recognized has important roles in maintain green house gasses that lead to global warming. Unfortunately, rainforest have been converted to different land uses that include conservation non forest function such commercial plantation. As tropical country, Indonesia has the second largest tropical rainforest in the world, but the pristine forests only remain in Sumatera, Kalimantan dan Papua. Despite government to protect the forest, deforestation and degradation are continue at the alarming rates. This study was designed to document the impact of forest functions on the frog diversity on Prafi District, Manokwari. We compare frog diversity from 3 land-uses: secondary forest, oil palm and cacao plantation, as well as frog diversity from oil palm plantation with different ages (6 years old, 30 years old and 38 years old). The study

\footnotetext{
* Korespondensi Penulis

Tlp : +628114877644

Email :yance.defretes@gmail.com
} 
shows that forest conversion has negative impacts on frog diversity significantly. Forest conversion to non forest function also allows introduce species such as Duttaphrynus melanostictus, Fejervarya cancrivora and F. limnocharis to dominate these altered habitats. Most surprisingly, none of native frogs ever recorded in plantations despite the fact the habitats were changed almost over 40 years old. During this study, we confirmed the present of F. limnocharis in Prafi District. The species may be accidently introduced to Papua in the recent years.

Keywords: frog diversity, the impact of forest conversion, Prafi District.

\section{Pendahuluan}

Hutan tropis merupakan salah satu ekosistem yang paling penting, karena merupakan habitat bagi hampir lebih dari separuh spesies yang ada di dunia. Selain sebagai habitat utama bagi ribuan spesies, hutan tropis dataran rendah memiliki fungsi penting lainnya, misalnya sebagai pengatur siklus hidrologi, penghasil oksigen dan menyerap dan menyimpan karbon monoksida salah satu komponen gas rumah kaca, penyebab pemanasan dan perubahan iklim global (Hartshorn, 2021). Hutan tropis, hanya tersebar di daerah tropis, atau daerah yang terletak antara 23 derajat Lintang Selatan dan 23 derajat Lintang Utara. Indonesia merupakan negara yang terletak di daerah tropis dan memiliki hutan tropis terbesar ke dua sesudah hutan tropis Brazil. Hutan tropis di Indonesia, tersebar luas di Pulau Kalimantan, Pulau Sumatera dan Pulau Papua, termasuk beberapa pulau kecil lainnya. Sama seperti hutan tropis di daerah lainnya, sebagian besar hutan tropis telah mengalami degradasi dan bahkan kehilangan fungsi hutannya (Conservation, 2020), karena konversi ke fungsi non hutan, misalnya, perkebunan, perumahan atau pusat-pusat pemerintahan. Kebanyakan hutan tropis yang tersisa di Indonesia berada di Pulau Kalimantan dan Pulau Papua (Provinsi Papua dan Papua Barat). Namun, nasib hutan-hutan ini tetap terancam, jika tidak ada tindakan nyata dari pemerintah dan masyarakat untuk meningkatkan perlindungan dan pengelolaan (Conservation, 2020). Kehilangan hutan (forest lost) atau degradasi (forest degradation) merupakan ancaman utama bagi pelestarian keanekaragaman hayati. Selain itu kehilangan hutan, terutama hutan gambut dan bakau, juga merupakan ancaman utama peningkatan emisi rumah kaca, salah satu penyebab pemanasan global dan perubahan iklim saat ini.

$$
\text { Papua Barat mempunyai }
$$

keanekaragaman jenis flora dan fauna yang tinggi dengan luas tutupan sekitar 89\% (Conservation, 2020; Kartikasari et al., 2012). Walaupun tingkat kehilangan hutan (deforestasi) relatif rendah di Provinsi Papua Barat, namun tingkat degradasi hutannya tercatat tinggi. Analisa data tutupan hutan lahan kering primer tahun 2018-2019 di Provinsi Papua Barat menunjukkan angka deforestasi sekitar 2 juta hektar. Kebanyakan deforestasi berasal dari perubahan fungsi hutan menjadi kebun atau pusat-pusat pemerintahan baru, dan pembangunan infrastruktur lainnya, terutama pembuatan jalan. Dampak langsung perubahan ini masih menjadi topik pembicaraan diberbagai seminar pada kalangan penggiat konservasi dan akademisi. Penelitian ini bertujuan untuk mencatat dampak perubahan fungsi hutan terhadap keanekaragaman katak di Daratan Rendah Prafi, Kabupaten Manokwari.

Katak dipilih dalam penelitian karena sebagai bioindikator kondisi lingkungan (Stebbins \& Cohen, 1997), taksa ini juga menyebar secara meluas, mulai dari dataran rendah sampai pegunungan tinggi, rentan pada perubahan lingkungan, relatif mudah disampel dan diidentifikasi serta beberapa spesies sangat menarik untuk pendidikan maupun advokasi mendukung kegiatan konservasi.

Kawasan hutan di Distrik Prafi, Kabupaten Manokwari, telah mengalami perubahan sekitar awal dan pertengahan tahun 1980, dimana sebagian besar hutan dan ekosistem dataran rendah kawasan ini ditentukan sebagai lokasi pemukiman transmigrasi, perkebunan sawit dan kakao serta pembukaan jalan baru. Selain itu, kawasan ini yang terletak dekat 
dengan pusat Kota Manokwari, memberikan kesempatan untuk melakukan penilitian dampak perubahan fungsi hutan terhadap keanekaragaman hayati katak. Penelitian ini akan difokuskan pada tiga tipe habitat utama yang berada di Distrik Prafi yaitu pada hutan sekunder, perkebunan sawit, dan perkebunan kakao.

\section{Metode}

\section{A. Waktu dan Tempat Penelitian}

Penelitian ini dilaksanakan pada Bulan JuliAgustus 2019 di tiga lokasi habitat penelitian yaitu: hutan sekunder Kampung Uyehegbrik, perkebunan kakao (38yo) Kampung Aimasi dan perkebunan sawit (38yo) Kampung Udapi Hilir. Kemudian dilanjutkan pengambilan data pada bulan Desember 2019 di dua lokasi habitat yaitu: sawit (30yo) Kampung Waseki Indah dan Sawit (6yo) Kampung Prafi Mulya. Peta lokasi penelitian dapat dilihat pada Gambar 1.

Untuk lokasi penelitian sawit dan kakao dibedakan dari umur tanam dan selanjutnya ditulis dengan "yo" (year old), sehingga penulisan sawit (38yo) menunjukkan perkebunan sawityang ditanaman 38 tahun lalu. Berdasarkan hasil analisa awal data pada Bulan Juli 2019, kegiatan penelitian dilanjutkan pada Desember 2019, terutama pada perkebunan sawit yang berbeda umur tanam (yakni 30yo dan 6yo), untuk melihat apakah ada perbedaan keragamanan spesies katak pada perkebunan sawit dengan umur tanam yang berbeda, dan juga antara perkebunan sawit maupun dengan dua lokasi penelitian lainnya (hutan sekunder dan kakao).

\section{B. Alat dan Bahan}

Alat yang akan digunakan untuk penelitian ini yaitu senter, GPS, termohygrometer, digital caliper, sarung tangan, tupperware, pinset, plastik spesimen, meter roll, tali rafia, dan label spesimen. Bahan yang akan digunakan untuk penelitian ini yaitu kloroform, formalin $10 \%$, alkohol $70 \%$ dan etanol $100 \%$ untuk pengawetan dan analisa jaringan.

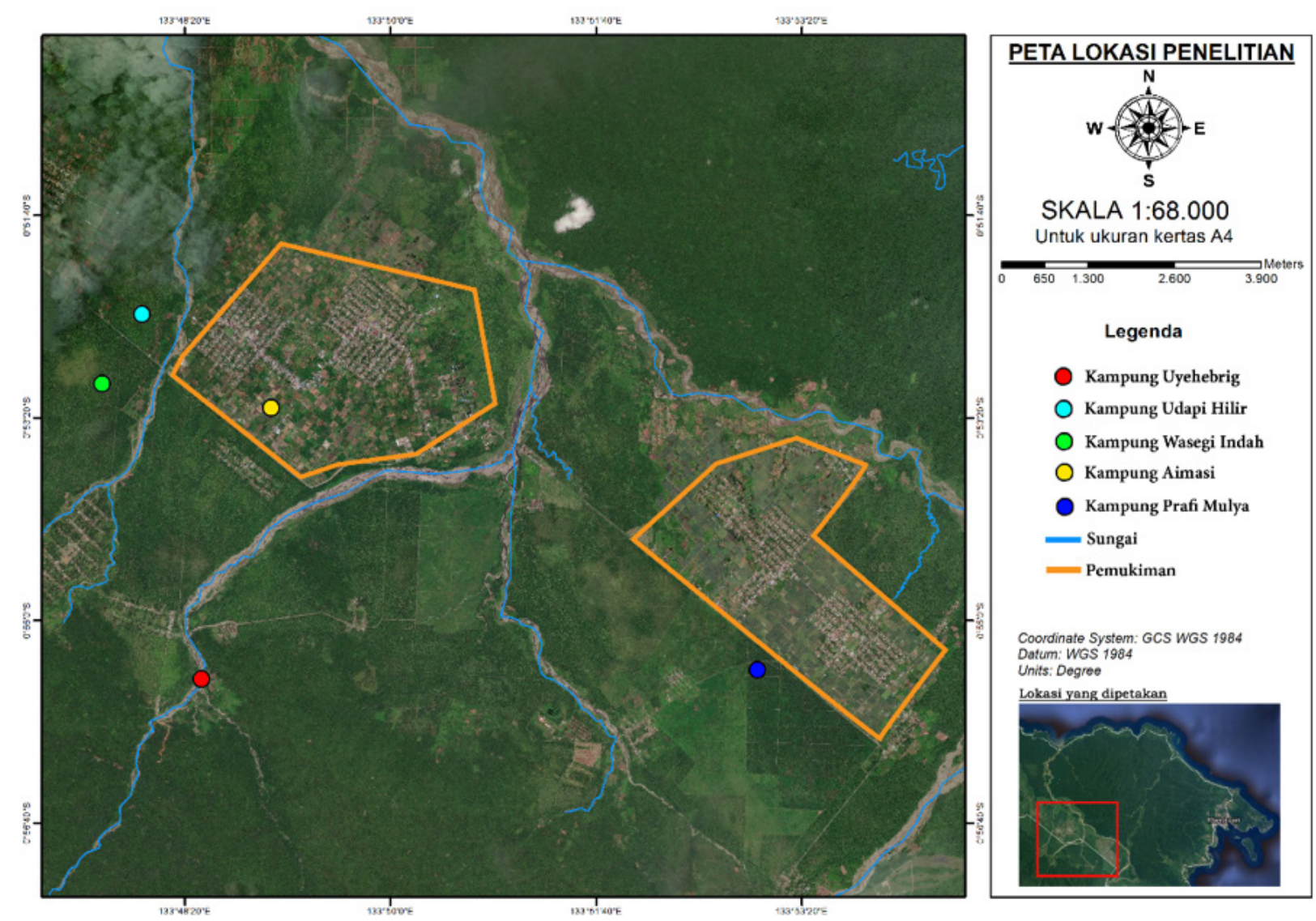

Gambar 1. Lokasi Penelitian (Apsyari, 2020) 


\section{Teknik Pengambilan Sampel dan Pengawetan Spesimen}

Pengambilan sampel menggunakan metode line transect yang dibuat secara acak (random) pada lokasi penelitian. Pada tiap lokasi penelitian dibuat 5 transek sepanjang $100 \mathrm{~m}$ dan lebar $5 \mathrm{~m}$ (sehingga luas tiap transek $5 \mathrm{~m} \times 100 \mathrm{~m}$ ), sehingga luas daerah sampel per lokasi penelitian adalah $5 \times(500 \mathrm{~m})$ atau 2.500 m2. Katak akan disurvei menggunakan VAES (Visual Audio Encounter Surveys) (Crump \& Jr., 1994; Heyer et al., 1994) , artinya katak akan dicatat berdasarkan hasil penglihatan maupun pengdengaran dalam tiap transek.

Pengamatan dan pengumpulan sampel dilakukan pada malam hari pukul 19.00-21.00 WIT oleh 4 orang peneliti dan pembantu peneliti. Data dan informasi yang dikumpulkan termasuk tipe habitat, substrat, keadaan habitat, suhu, kelembaban, ketinggian untuk setiap spesies yang berhasil ditangkap. Katak diidentifikasi menggunakan The Frogs of New Guinea and the Solomon Islands (Menzies, 2006) dan Field Guide to Frogs of The Mimika RegionPapua, Indonesia (Richards et al., 2002). Katak yang tidak dapat diidentifikasi di lapangan, akan difoto dengan high resolution (minimal 300pixel atau dalam raw format), kemudian meminta bantuan identifikasi ahli katak.

Semua individu katak yang berhasil diamati atau ditangkap, dimasukkan dalam plastik, kemudian diteliti lebih lanjut untuk memastikan jenis dan memastikan proses pencatatan. Spesies yang umum diamati atau dijumpai akan dicatat dan dilepaskan kembali pada akhir survei. Namun, beberapa individu dari spesies yang tidak umum, dibuatkan spesimen untuk penelitian lebih lanjut. Spesies yang tidak dapat diidentifikasi atau atas pertimbangan tertentu, akan dibuat spesimen untukproses penelitianlanjutan. Spesimen yang dibuat akan disimpan di Laboratorion Zoologi, Fakultas Matematika dan Ilmu Pengetahuan Alam, Universitas Papua. Sebelum melakukan pembiusan hal pertama yang dilakukan yaitu menentukan katak yang akan dibius, kemudian katak dimasukkan kedalam wadah yang berisi kloroform 100\% hingga katak terbius. Sebelum diawetkan, dilakukan pembedahan untuk mengambil liver katak sebagai sampel jaringan, dan diawetkan dalam tabung vail yang berisi etanol 100\%. Setelah itu katak akan dimasukkan kedalam wadah yang beralas tisu dan formalin $10 \%$, katak diatur sedemikian rupa sehingga memudahkan pengukuran sampel dikemudian hari. Spesimen didiamkan selama 24 jam kemudian dipindahkan botol spesimen yang telah diberi alkohol 70\%.

\section{Analisis Data}

Analisis data yang akan digunakan adalah kondisi habitat, menghitung indeks keanekaragaman Shannon $\left(\mathrm{H}^{\prime}\right)$, indeks kemerataan atau evenness (E) serta kesamaan jenis Sronsren Indeks pada lokasi yang berbeda. Perhitungan aspek keanekaragaman akan menggunakan rumus berikut:

1) Indeks Keragaman Spesies -Shannon Diversity Index

Indeks Shannon (Magurran, 2013) digunakan untuk mengukur keanekaragaman spesies pada setiap tipe habitat, dengan rumus:

$$
\begin{aligned}
& \mathrm{H}^{\prime}=-\sum p i \ln p i \\
& \mathrm{pi}=\mathrm{ni} / \mathrm{N}
\end{aligned}
$$

\author{
Keterangan: \\ $\mathrm{H}^{\prime}$ : Indeks keanekaragaman spesies \\ Pi : Proporsi jenis \\ ni : Jumlah individu untuk spesies yang \\ diamati \\ $\ln :$ Log normal \\ $\mathrm{N}$ : Jumlah total individu semua spesies
}

\section{2) Indeks kemerataan (Evenness)}

Selain itu dari indeks keanekaragaman Shannon selanjutnya akan dihitung indeks kemeratan (evenness) (Magurran, 1988) digunakan untuk mengetahui kemerataan penyebaran herpetofauna dengan rumus:

E

Keterangan :

E : Indeks Kemerataan spesies

H': Indeks Keanekaragaman Shannon

$S$ : Jumlah spesies

3) Perbandingan Spesies pada Dua Lokasi Penelitian

Untuk mengetahui perbandingan spesies (indeks keragaman) pada dua lokasi akan menggunakan Hutcheson t-test (Gardener, 2017), dengan rumus sebagai berikut: 


$$
t=\frac{H_{a}-H_{b}}{\sqrt{s_{H_{a}}^{2}+s_{H_{b}}^{2}}}
$$

Keterangan:

$\mathrm{Ha}$ : Shannon Indeks pada lokasi a

$\mathrm{H} b$ : Shannon indeks pada lokasi b

$\mathrm{S}^{2} \mathrm{Ha}$ : Varians Shannon Indeks lokasi a

$\mathrm{S}^{2} \mathrm{H} b$ : Varians Shannon Indeks lokasi b

Untuk menghitung varians akan meggunakan rumus sebagai (Magurran, 2013).

$\operatorname{Var} H^{\prime}=\frac{\sum P i(\operatorname{In} P i) 2-\left(\sum P i, I n P i\right) 2}{N}=\frac{S-1}{2 N 2}$

Keterangan :

$\mathrm{H}^{\prime} \quad$ : Indeks Keanekaragaman spesies

ni : Jumlah individu untuk spesies yang diamati

$\mathrm{N} \quad$ : Jumlah total individu semua spesies

$\mathrm{S} \quad$ : Jumlah spesies

Dalam analisa data semua perhitungan ini akan menggunakan formula perhitungan yang telah dibuat dalam Excell (Gardener, 2017).
4) Tingkat Kesamaan Komposisi Spesies Katak

Untuk melihat tingkat kesamaan komposisi spesies amfibi (similarity) antara tipe habitat, akan menggunakan Sorensen Indeks Similarity (Krebs, 1999).

$$
\mathrm{S}_{\mathrm{s}}=2 \mathrm{a} / 2 \mathrm{a}+\mathrm{b}+\mathrm{c}
$$

\section{Keterangan:}

Ss : Sorensen Similiarity

a : Jumlah spesies amfibia yang terdapat di lokasi penelitian a dan $\mathrm{b}$

b : Jumlah spesies amfibia yang terdapat di lokasi penelitian $b$

c. : Jumlah spesies amfibia yang terdapat di lokasi penelitian a

Nilai Sorensen berkisar antara 0-1, dimana nilai mendekati 1 menunjukkan tingkat kesamaan komposisi spesies (similarity) yang tinggi.

5) Indeks Kelimpahan Relatif

$$
K R=\frac{n i}{N} \times 100 \%
$$

Tabel 1.

Daftar Spesies dan Jumlah Individu Katak yang Ditemukan pada Lima Lokasi Penelitian

\begin{tabular}{llccccc}
\multicolumn{1}{c}{ Family } & \multicolumn{1}{c}{ Spesies } & HH & HK & HS1 & HS2 & HS3 \\
Bufonidae & Duttaphrynus melanostictus & 6 & 12 & 15 & 7 & 9 \\
\hline Ceratobatrachidae & Cornufer papuensis & 21 & - & 13 & 11 & 18 \\
\hline Dicroglossidae & Fejervarya cancrivora & 8 & 22 & 24 & 5 & 6 \\
\hline Dicroglossidae & Fejervarya limnocharis & - & 19 & 29 & 13 & 10 \\
Dicroglossidae & Limnonectes sp. & - & 6 & - & - & - \\
Hylidae & Litoria infrafrenata & 3 & 2 & - & - & - \\
Microhylidae & Callulops sp. & 1 & - & - & - & - \\
Microhylidae & Cophixalus sp. & 20 & - & - & - & - \\
Ranidae & Papurana arfaki & 2 & - & - & - & - \\
Ranidae & Papurana cf. grisea & 3 & - & - & - & - \\
Total Individu & & $\mathbf{6 4}$ & $\mathbf{6 1}$ & $\mathbf{8 1}$ & $\mathbf{3 6}$ & $\mathbf{4 3}$ \\
Total Spesies & & $\mathbf{8}$ & $\mathbf{5}$ & $\mathbf{4}$ & $\mathbf{4}$ & $\mathbf{4}$ \\
\hline
\end{tabular}

Keterangan: HH = Habitat Hutan, HK = Habitat Kakao (38 yo), HS1 = Habitat Sawit (38 yo), HS2 = Habitat Sawit (30 yo), HS3 = Habitat Sawit (6 yo), -: Tidak terdapat spesies 
Keterangan :

KR : Kelimpahan Relatif

ni : Jumlah individu spesies ke i

$\mathrm{N}$ : Jumlah individu seluruh (total) spesies

\section{HaSil DAN PEMbahasan}

\section{A. Keragaman Katak}

Total 10 spesies katak dari 6 famili berhasil dicatat dan diidentifikasi dalam penelitian ini (Tabel 1). Lima lokasi penelitian meliputi: hutan, perkebunan kakao (38yo), perkebunan sawit 1 (38yo), sawit 2 (30yo), dan sawit 3 (6yo). Perkebunan sawit 1(38yo) dan kakao ditanam sekitar 38 tahun lalu (Holle, 2000; Kesaulija dkk, 2014) dan sawit ditanam kembali (peremajaan) sekitar 6 tahun lalu (tahun 2014). Hutan sekunder, merupakan bekas kebun tua yang memulai pertumbuhan kembali, dimana terdapat beberapa pohon dengan diameter $30 \mathrm{~cm}$.

Tabel 1 menunjukkan hasil penelitian pada pada lima lokasi menunjukkan bahwa spesies katak yang berhasil diamati dalam penelitian ini sangat beranekaragam. Tabel 2 menyajikan hasil pengukuran faktor lingkungan (suhu dan kelembaban) dan fisik (ketinggian) di lima lokasi penelitian. Hasil pengukuran ini menunjukkan bahwa tidak ada perbedaan yang menyolok antara lokasi penelitian.

Family katak yang paling banyak dicatat jumlah individunya berasal dari Dicroglossidae, dengan jumlah total 142 individu. Sedangkan family yang memiliki jumlah individu sedikit berasal dari Ranidae dan Hylidae, masing- masing dengan 5 individu. Menarik dari penelitian semua spesies yang diintroduksi Duttaphrynus melanostictus (Bufonidae), Fejervarja crancivora dan $F$. limnocharis (Dicroglossidae) memiliki jumlah individu yang banyak, terutama pada habitat perkebunan (baik sawit maupun kakao). Adanya $F$. limnocharis (katak sawah) merupakan informasi terbaru kehadiran spesies ini di Papua. Spesies distribusi hampir seluruh Asia, namun hanya sampai di Pulau Flores.

Hasil pengamatan menunjukkan bahwa spesies katak yang memiliki populasi tinggi terdapat pada habitat sawit (38yo), yaitu 81 individu, walaupun hanya dari 4 spesies. Populasi paling rendah dicatat pada habitat sawit (30yo). Jumlah individu spesies yang tertinggi pertama pada habitat sawit (38yo) yaitu spesies Fejervarya limnocharis dengan jumlah 29 individu sedangkan spesies yang terendah yaitu spesies dengan jumlah 6 individu. Spesies yang tertinggi kedua pada habitat hutan yaitu spesies Cornufer papuensis dengan jumlah 21 individu sedangkan spesies yang terendah yaitu spesies Callulops sp. dengan jumlah 1 individu. Spesies yang tertinggi ketiga terdapat pada habitat kakao (38yo) yaitu dengan jumlah 20 individu, sedangkan spesies terendah yaitu spesies Litoria infrafrenata dengan jumlah 2 individu.

Hasil penelitian menunjukkan bahwa ada perubahan atau pengaruh perkebunan terhadap jumlah spesies katak dan juga jumlah individu, baik pada perkebunan kakao maupun perkebunan sawit terlepas lama waktu tanam

Tabel 2.

Pengukuran Faktor Lingkungan di Lokasi Penelitian

\begin{tabular}{|c|c|c|c|c|c|}
\hline Kampung & Habitat & $\begin{array}{l}\text { Ketinggian } \\
\text { (m dpl) }\end{array}$ & $\begin{array}{l}\text { Suhu } \\
\left({ }^{\circ} \mathrm{C}\right)\end{array}$ & $\begin{array}{c}\text { Kelembaban } \\
(\%)\end{array}$ & Koordinat \\
\hline Uyehegbrik & $\begin{array}{c}\text { Hutan } \\
\text { sekunder }\end{array}$ & 174 & $28-29$ & $71-96$ & S 00'55'25.9" E133'48'28" \\
\hline Aimasi & Kakao (30yo) & 153 & $25-29$ & $71-96$ & S $00^{\prime} 53^{\prime} 15^{\prime \prime}$ E $133^{\prime \prime} 49^{\prime \prime} 01^{\prime \prime}$ \\
\hline Prafi Mulya & Sawit (6 yo) & 146 & $28-30$ & $71-96$ & 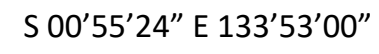 \\
\hline Udapi Hilir & Sawit (38 yo) & 158 & $26-29$ & $71-96$ & S 00’53'01" E 133'47'52" \\
\hline Waseki Indah & Sawit (30 yo) & 166 & $28-29$ & $71-96$ & S 00'53'04" E 133'47'39'E \\
\hline Kisaran & & $146-174$ & $25-30$ & $71-96$ & \\
\hline
\end{tabular}




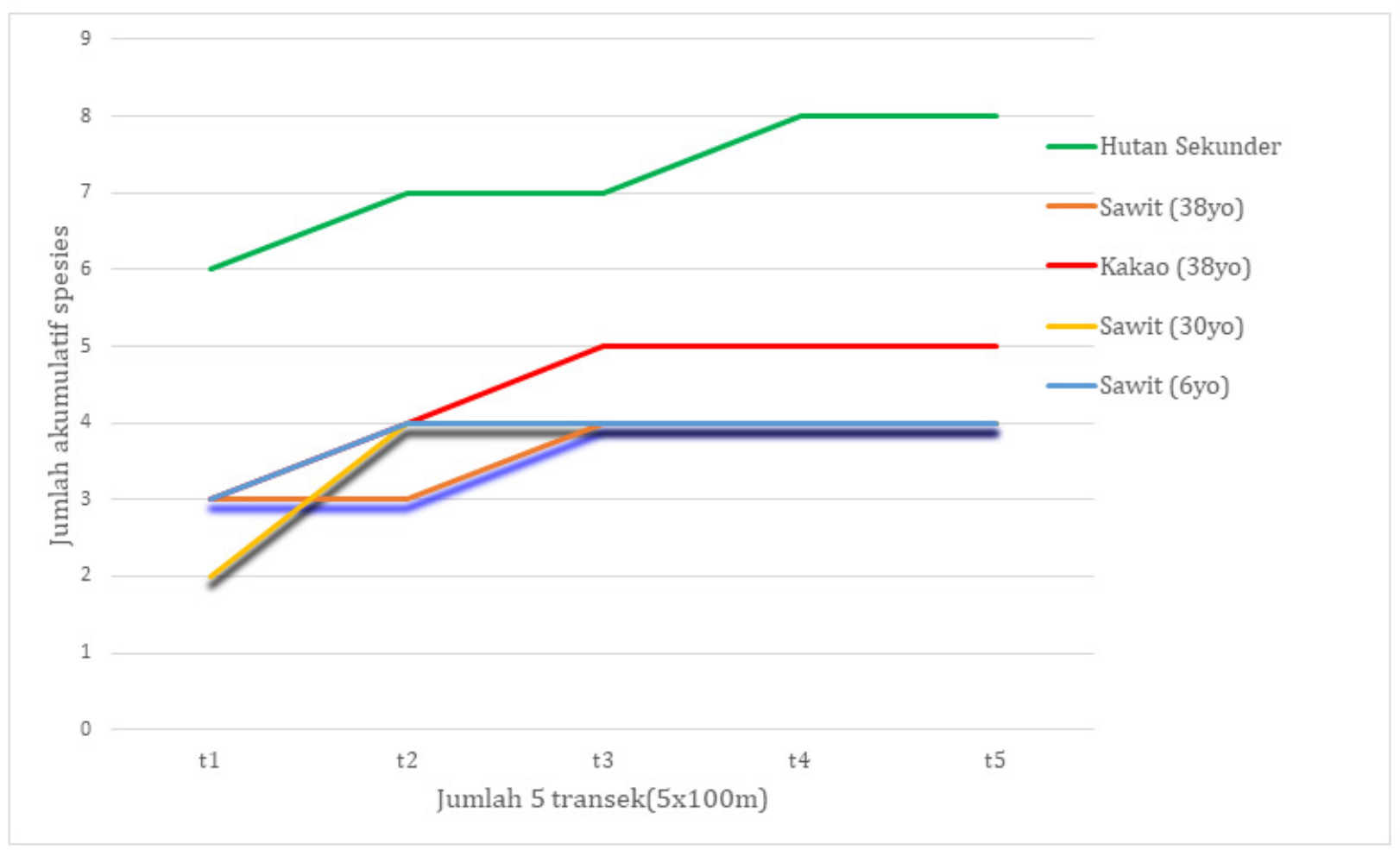

Gambar 2. Grafik Akumulasi Spesies Dalam 5 (5x100 m) Transek Pengamatan

dan jarak yang relatif dekat dengan hutan sekunder. Tabel 1 menunjukkan bahwa hanya ada 1 dari 8 spesies yang berada di hutan sekunder pada hutan sawit. Tabel 1 ini juga menunjukkan bahwa hanya ada 4 famili yang tercatat di hutan sekunder dan hanya 1 famili saja berada di perkebunan sawit atau perkebunan sawit telah berpengaruh pada keanekaragaman hayati katak (hanya 25\% saja spesies yang sama dengan spesies yang dicatat di hutan sekunder), walaupun perkebunan ini telah berumur hampir 40 tahun dan berjarak sekitar 6-8 $\mathrm{km}$ dari hutan sekunder. Hasil penelitian menunjukkan bahwa jumlah spesies yang berhasil diamati di perkebunan sawit sama semua umur tanam, maka dalam analisa data dan pembahasan akan disebut perkebunan sawit saja; kecuali pembahasan khusus keragamanan hayati pada perkebunan sawit tertentu, maka sawit akan disebut berdasarkan masa tanaman.

Tabel 3.

Jumlah Spesies, Famili, Individu dan Shannon-Diversity Indeks dan Evenness

\begin{tabular}{cccccc} 
& $\begin{array}{c}\text { Hutan } \\
\text { Sekunder }\end{array}$ & $\begin{array}{c}\text { Kakao } \\
(38 y 0)\end{array}$ & $\begin{array}{c}\text { Sawit } \\
\text { (38yo) }\end{array}$ & $\begin{array}{c}\text { Sawit (30yo) } \\
\text { Sawit } \\
\text { (6yo) }\end{array}$ \\
\hline Jumlah Spesies (S) & 8 & 5 & 4 & 4 & 4 \\
\hline Jumlah Family & 6 & 3 & 3 & 3 & 43 \\
\hline Jumlah Individu (N) & 64 & 61 & 81 & 36 & 1.305 \\
\hline Shannon Diversity Indeks (H') & 1,671 & 1,391 & 1,334 & 1,322 & 0,95 \\
\hline
\end{tabular}


Akumulasi spesies katak yang ditunjukkan dalam Gambar 2 ternyata berbeda untuk setiap lokasi pengamatan. Jumlah spesies katak yang diamati di habitat hutan sekunder sebanyak 6 spesies, sedangkan pada dua habitat lainnya yaitu pada kakao dan sawit masing-masing ditemukan 3 spesies. Terjadi penambahan spesies pada hari kedua dan hari ketiga untuk habitat hutan, habitat kakao dan habitat sawit.

\section{B. Indeks Keanekaragaman Spesies Katak}

Indeks keanekaragaman katak pada tiga lokasi penelitian dihitung dengan menggunakan rumus Indeks Diversity Shannon (Magurran, 2013) dengan menggunakan menggunakan Shannon Diversity t-test Calculator,yang dibuat dalam Excell (Gardener, 2017).

Gambar 3 menunjukkan keragaman spesies katak pada lokasi penelitian. Menggunakan kriteria Odum (1993) menyebutkan bahwa suatu lokasi atau habitat memiliki nilai $\mathrm{H}^{\prime}<1$, berarti keanekaragaman rendah, jika nilai $\mathrm{H}^{\prime}$ antara 1-3 berarti keanekaragaman sedang, dan $\mathrm{H}^{\prime}>3$ berarti keanekaragaman tinggi; maka dapat disimpulkan bahwa ketiga lokasi penelilitian memiliki tingkat keanekaragaman spesies sedang.

\section{Indeks Kemerataan Spesies (Evenness)}

Indeks kemerataan spesies menyangkut dual penting, jumlah spesies ( $S$ ) dan jumlah individu pada tiap spesies. Lokasi dengan jumlah individu yang merata atau sama pada tiap spesies (evenness mendekati 0 menunjukkan lokasi dengan keragaman tinggi). Indeks kemerataan spesies berkisar dari 0-1, dimana nilai $\mathrm{E}$ yang rendah atau mendekati 0 menunjukkan keragaman spesies yang tinggi (Krebs, 1999). Gambar 4 menunjukkan nilai evenness dari tiga lokasi penelitian.

Gambar 4 dan Tabel 4 menunjukan Indeks Kemerataan katak pada tiga lokasi penelitian memiliki nilai kemerataan spesies berbeda. Lokasi hutan sekunder memiliki

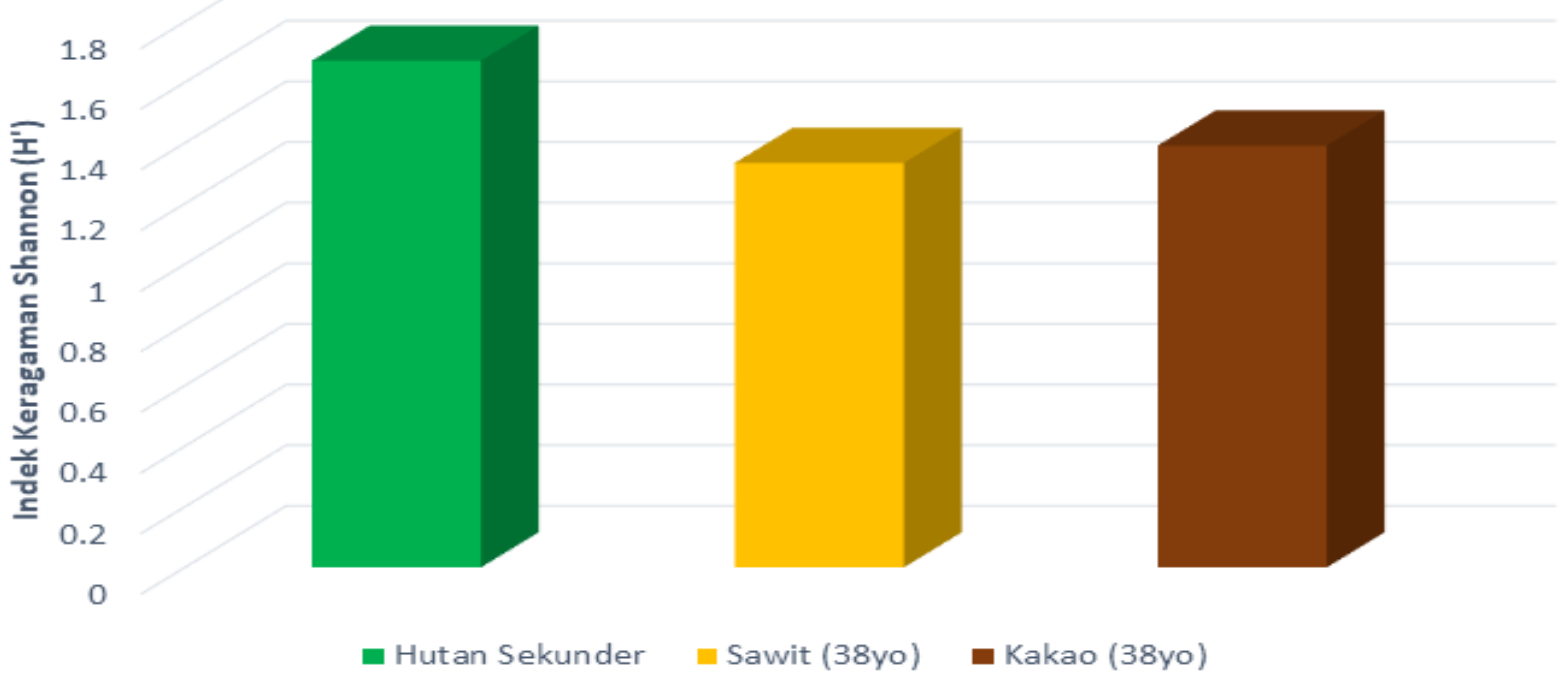

Gambar 3. Indeks Keanekaragaman Shannon Spesies dari Tiga Habitat

Tabel 4.

Kemerataan Spesies Antara Lokasi Penelitian

\begin{tabular}{lcccc}
\hline Habitat & S & Ln $(S)$ & $H^{\prime}$ & E \\
\hline Hutan sekunder & 8 & 2,079442 & 1,671 & 0,8 \\
\hline Kakao (38yo) & 5 & 1,609438 & 1,391 & 0,9 \\
\hline Sawit (38yo) & 4 & 1,386294 & 1,334 & 0,95
\end{tabular}




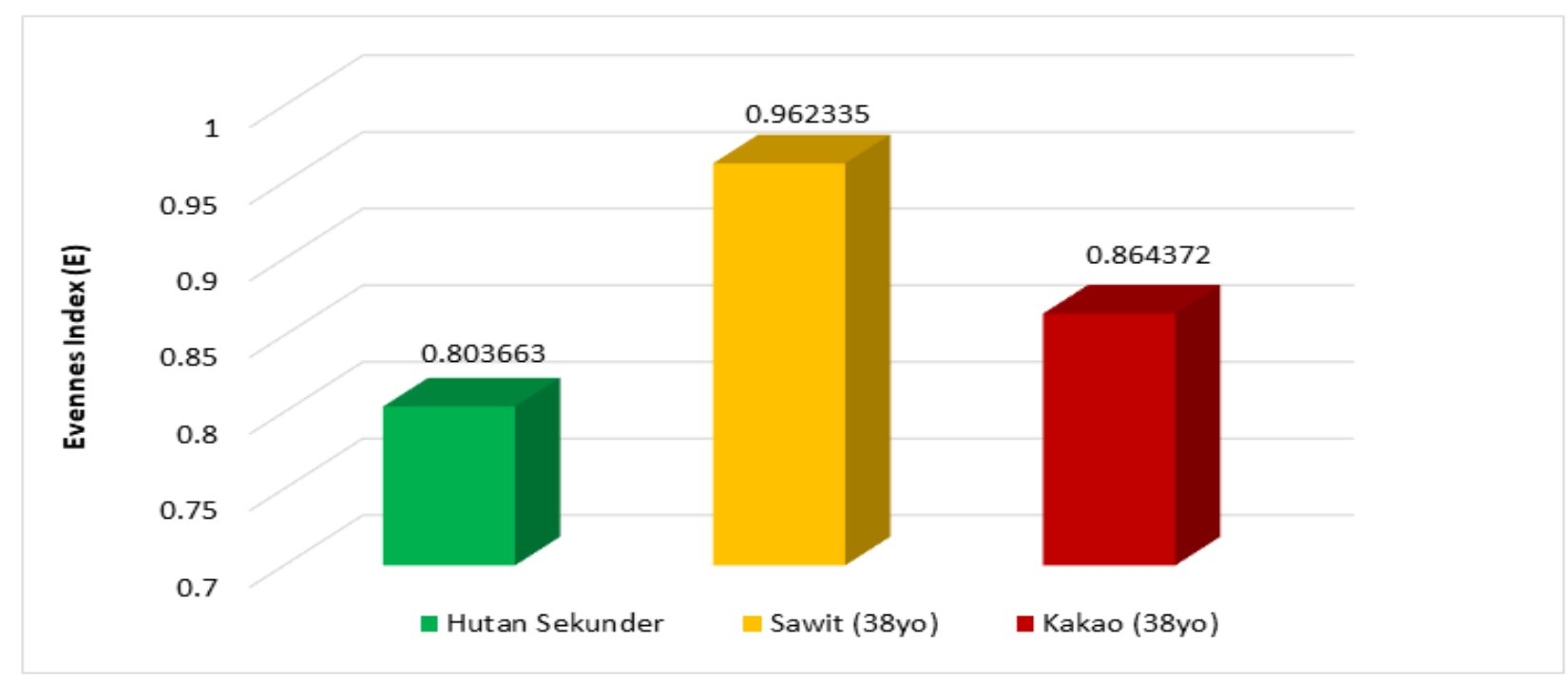

Gambar 4. Indeks Kemerataan Spesies

kemerataan spesies dengan nilai $\mathrm{E}=0,8$, sawit (38yo) memiliki kemerataan spesies dengan nilai $\mathrm{E}=0,96$ dan kakao (38yo) dengan nilai $\mathrm{E}=0,86$. Gambar 4 menyimpulkan bahwa hutan sekunder dan kakao (38yo) memiliki keragaman spesies lebih tinggi dari hutan sawit (38yo).

\section{Indeks Kesamaan Spesies (Similarity Index) antara Lokasi Penelitian}

Indeks Kesamaan Spesies atau Species Similarity Index digunakan untuk mengkaji tingkat kesamaan atau perbedaan spesies pada tiap lokasi penelitian. Indeks kesamaan spesies berkisar antara 0-1, dimana nilai yang mendekati 1 menunjukkan tingkat kesamaan spesies yang tinggi. Dalam penelitian ini menggunakan rumus Sorensen Similariy Coefficient (Krebs, 1989) dapat dilihat pada (Tabel 5).

Tabel 5 menunjukkan bahwa ada kesamaan sedang antara lokasi penelitian sawit (38yo) dan kakao (38yo), dan ada perbedaan antara kakao (38yo) dan hutan sekunder. Tabel 2 menunjukkan bahwa dari 8 spesies yang diamati di hutan sekunder hanya ada 2 spesies yang sama di kakao (38yo) dan hanya 3 spesies di sawit (38yo). Kalau diperhatikan semua spesies yang sama adalah spesies yang diintoroduksi ke Papua (Duttaphyrnus melanostictus, Fejervarya crancivora, dan F. limnocharis), dengan demikian dapat disimpulkan bahwa ada perbedaan antara komposisi spesies katak yang berada di hutan sekunder dengan spesies yang berada pada perkebunan sawit (38yo) dan kakao (38yo).

\section{E. Perbandingan Indeks Keanekaragaman Shannon pada Dua Lokasi}

Perbandingan indeks keanekaragaman spesies katak antara lokasi dihitung menggunakan rumus Hutcheson t-test (Gardener, 2017). Hasil penelitian yang dilakukan pada tiga lokasi pengamatan memiliki perbandingan spesies katak yang berbeda antara dua lokasi penelitian. Berikut ini perbandingan spesies katak pada masingmasing lokasi pengamatan :

Tabel 5.

Perbandingan Kesamaan Spesies antara Lokasi Penelitian

\begin{tabular}{|c|c|c|c|}
\hline Lokasi Penelitian & $\begin{array}{c}\text { Hutan } \\
\text { Sekunder }\end{array}$ & Sawit (38yo) & Kakao (38yo) \\
\hline Hutan Sekunder & & 0,5 & 0,4 \\
\hline Sawit (38yo) & & & 0.6 \\
\hline Kakao (38yo) & & & \\
\hline
\end{tabular}


1. Habitat Hutan Sekunder dan Habitat Sawit (38yo)

Hasil $t$-test perbedaan indeks keragaman spesies katak pada habitat hutan sekunder dan sawit (38yo), yaitu nilai t yaitu 3,062 dan nilai crictical 1,989, sehingga ada perbedaan signifikan. Berikut ini grafik perbandingan indeks keragaman spesies katak pada kedua lokasi penelitian dapat dilihat pada (Gambar 5).
2. Habitat Hutan Sekunder dan Kakao (38yo)

Hasil t-test perbedaan indeks keanekaragaman katak pada hutan sekunder dan dan kakao (38yo) adalah t-value 2,211 dan $t$-crictical 1,980, sehingga dapat disimpulkan ada perbedaan yang signifikan (Gambar 6).

\section{Habitat Sawit (38yo) dan Kakao(38yo)}

Hasil $t$-test indek keragaman katak pada habitat sawit (38yo) dan kakao (38yo) adalah $\mathrm{t}$-value 0,089 dan $t$ - crictical 1,985), sehingga dapat disimpulkan tidak ada perbedaan yang signifikan atau nyata (Gambar 7).

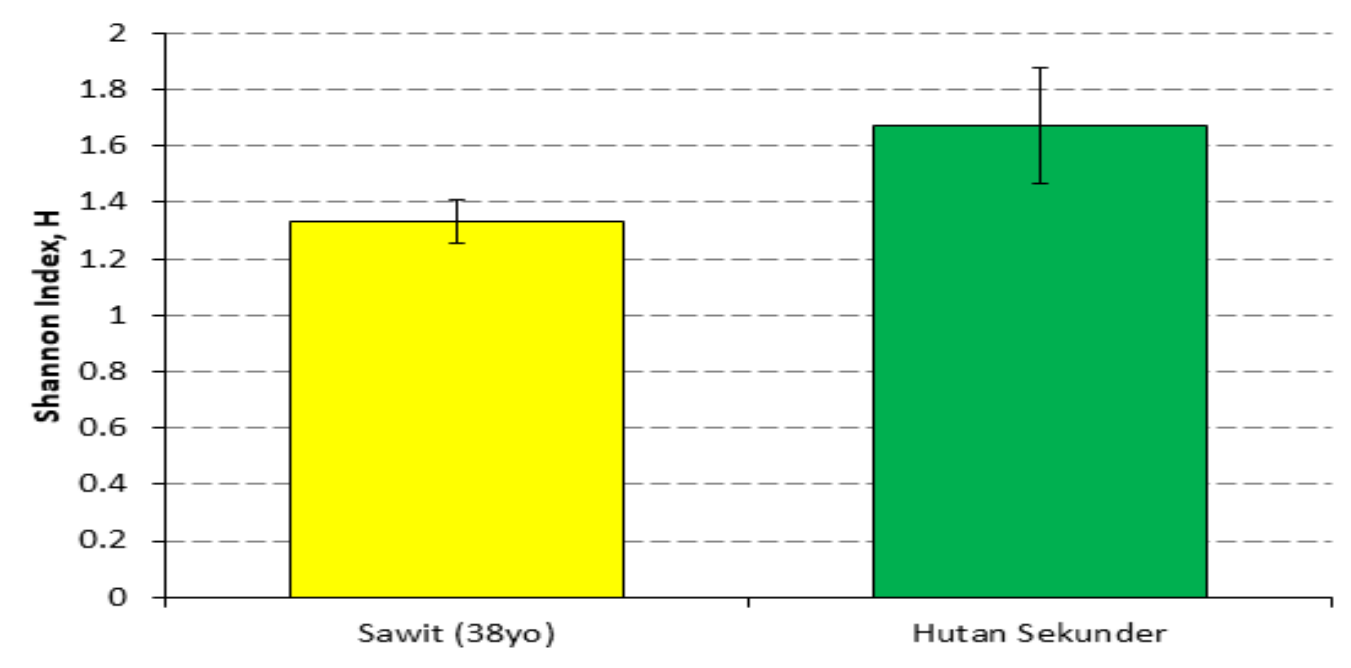

Gambar 5. Perbandingan Shannon Diversity Indeks antara Hutan Sekunder dan Sawit (38yo)

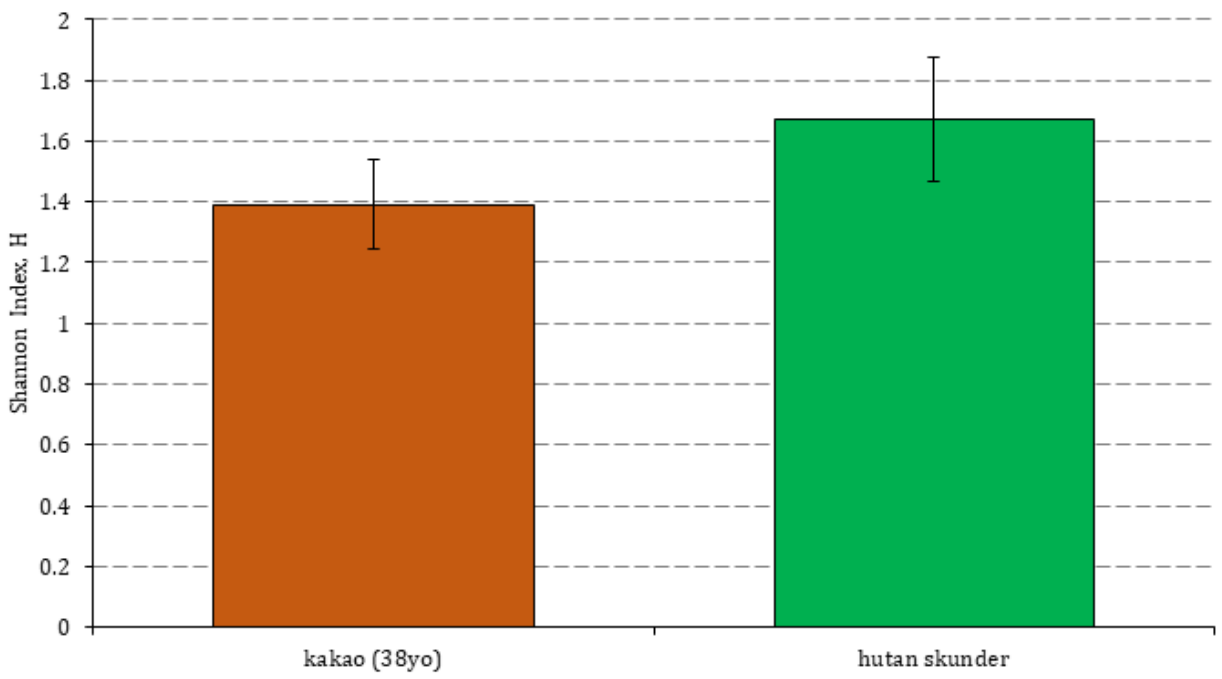

Gambar 6. Perbandingan Keragaman Spesies Shannon pada kakao(38yo) dan Hutan Sekunder 


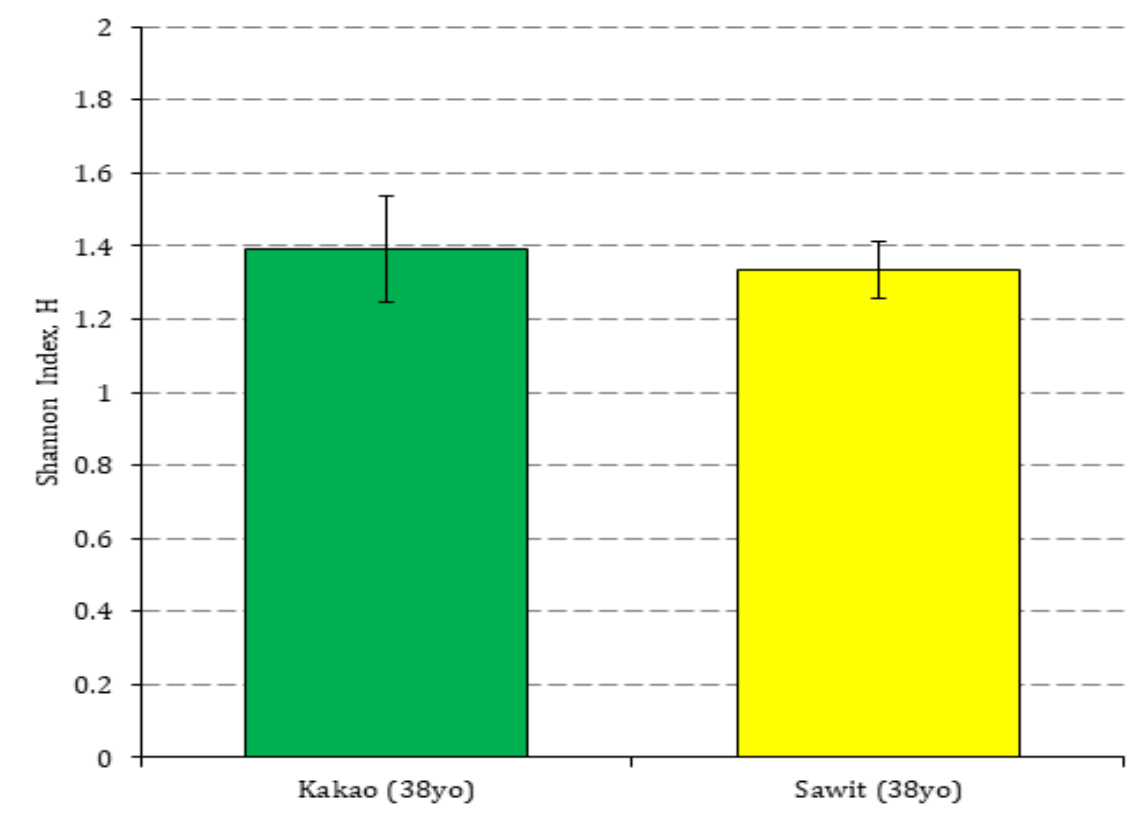

Gambar 7. Perbandingan Keragamanan Shanonn Indeks antara Kakao (40yo) dan Sawit (38yo)

Tabel 6.

Hasil T-Test Perbandingan Shannon Diversity Indeks pada Lokasi Penelitian

\begin{tabular}{cccccc}
\hline No & Perbandingan H' & t-critical & t-value & $\mathbf{p}$ & Keterangan \\
\hline 1 & Hutan Sekunder vs Sawit (38yo) & 1,989 & 3,062 & 0.01 & signifikan \\
\hline 2 & Hutan Sekunder vs Kakao (38yo) & 0,177 & 1,990 & 0,1 & signifikan \\
\hline 3 & Sawit (38yo) vs Kakao (38y0) & 1,985 & 0,689 & 0,5 & tidak signifikan \\
\hline
\end{tabular}

\section{F. Kelimpahan Relatif Spesies Katak}

Hasil penelitian menunjukkan adanya yang perbedaan kelimpahan spesies pada semua lokasi penelitian. Namun, ada 3 spesies introduksi dan $P$. papuaensis merupakan spesies dengan kelimpahan yang tinggi pada semua lokasi penelitian (Gambar 8).

Gambar 8 menunjukkan bahwa kelimpahan relatif didominasi oleh 3 spesies introduksi $(F$. limocharis, $F$. crancivora dan D. melanostictus) dan Cornufer papuensis adalah spesies yang dominan.

Ada kesamaan antara kelimpahan relatif (Gambar 8) dan dominan spesies di tiap lokasi penelitian (Gambar 9). Spesies Cornufer papuensis dan Cophixalus sp. terlihat dominan di hutan sekunder, tetapi tidak demikian di perkebunan sawit dan kakao. F. limnocharis, F. crancivora dan D. melanostictus merupakan spesies introduksi yang mendominasi di perkebunan sawit dan kakao. Dapat disimpulkan perubahan habitat dari hutan ke perkebunan, di satu sisi merupakan ancaman bagi spesiesspesies asli Papua, tetapi merupakan habitat baik bagi spesies yang diintroduksi.

\section{G. Keragaman Spesies Perkebunan Sawit}

Dari penjelasan sebelumnya terlihat ada perbedaan keragaman katak antara hutan sekunder dan hampir semua lokasi sawit, dimana semua lokasi sawit hanya memiliki $25 \%$ spesies yang berada di hutan sekunder. Bukan hanya keragaman spesies, tetapi ada perbedaan kesamaan komposisi spesies (similarity index) pada hutan sekunder dan perkebunan. Hasil penelitian menunjukkan bahwa spesies introduksi mendominasi sawit 


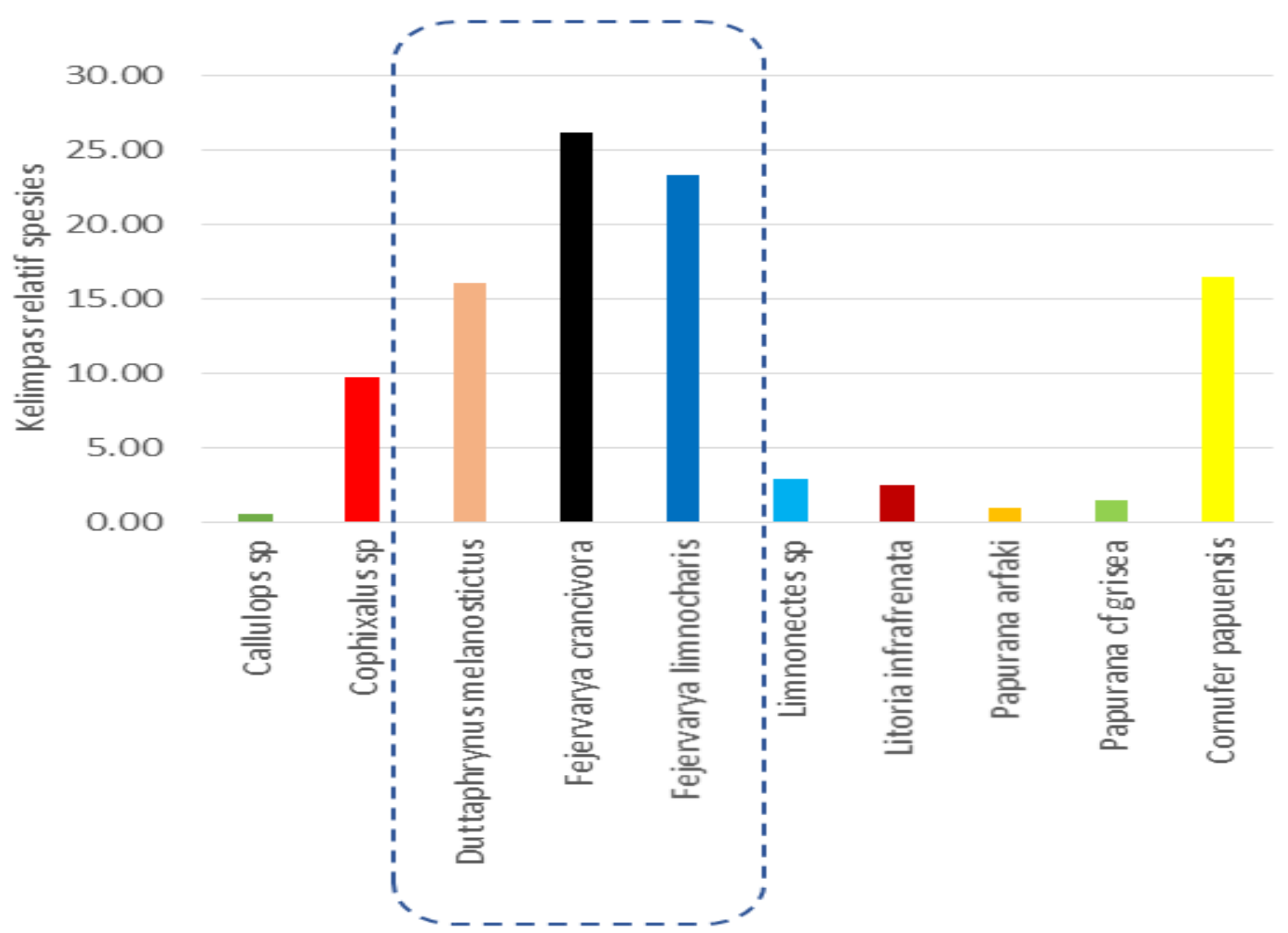

Gambar 8. Kelimpahan Relatif Spesies Katak Lokasi Penelitian (hutan sekunder, sawit-38yo, dan kakao-30yo)

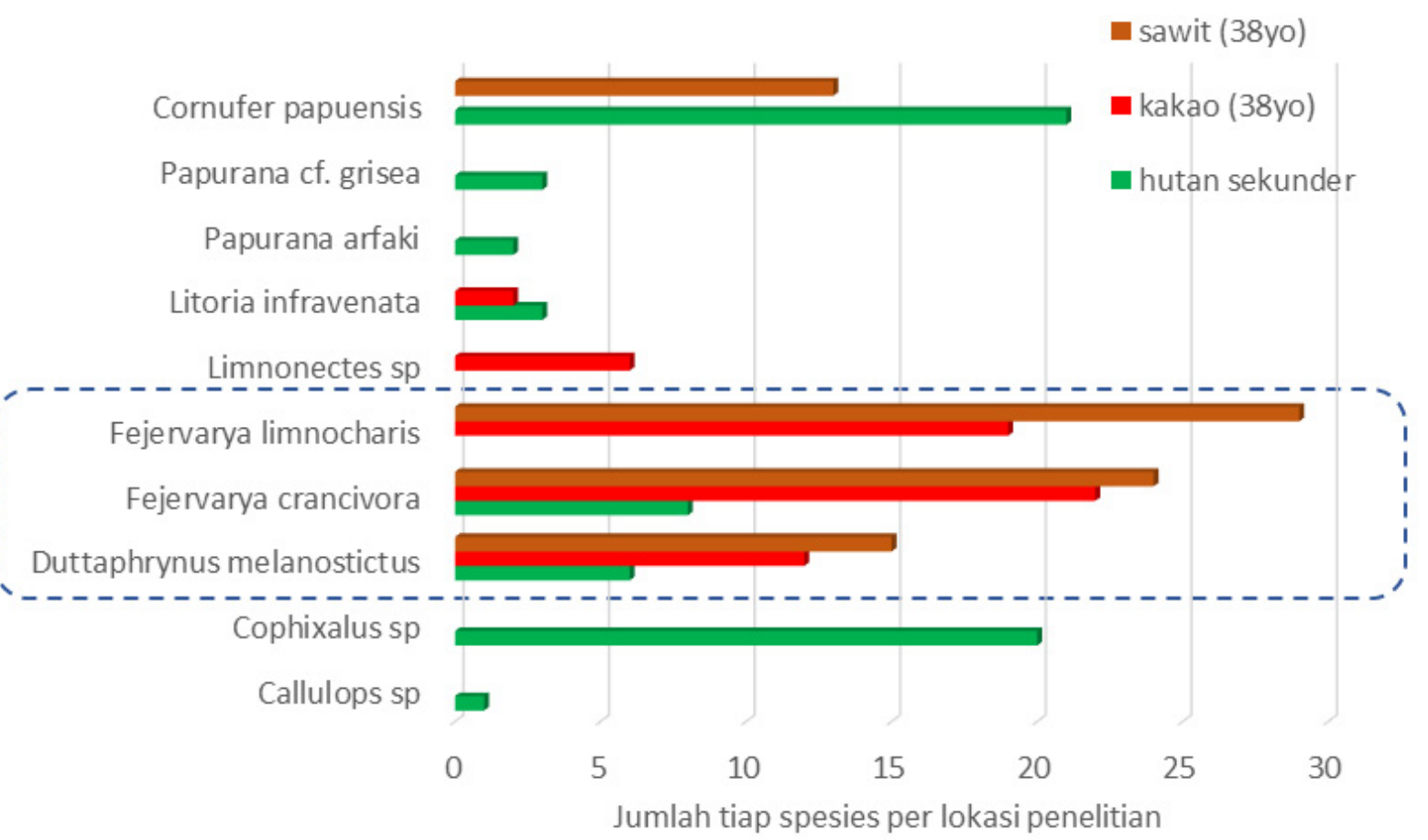

Gambar 9. Spesies Dominan Dengan Jumlah Individu Per Lokasi Penelitian 
Tabel 7.

Rangkuman Keragaman Katak pada Perkebunan Sawit Berbeda Umur Tanam

\begin{tabular}{|c|c|c|c|c|}
\hline Family & Spesies & Sawit (38yo) & $\begin{array}{c}\text { Sawit (30 } \\
\text { yo) }\end{array}$ & Sawit (6yo) \\
\hline Bufonidae & Duttaphrynus melanostictus & 15 & 7 & 9 \\
\hline Ceratobatrachidae & Cornufer papuensis & 13 & 11 & 18 \\
\hline Dicroglossidae & Fejervarya cancrivora & 24 & 5 & 6 \\
\hline Dicroglossidae & Fejervarya limnocharis & 29 & 13 & 10 \\
\hline \multicolumn{2}{|c|}{ Total spesies (S) } & 4 & 4 & 4 \\
\hline \multicolumn{2}{|c|}{ Total Individu (n) } & 81 & 36 & 43 \\
\hline \multicolumn{2}{|c|}{ Shannon Diversity Indeks ( $\left.\mathrm{H}^{\prime}\right)$} & 1,33 & 1,32 & 1,3 \\
\hline \multicolumn{2}{|c|}{ Evenness (E) } & 0,95 & 0,95 & 0,95 \\
\hline
\end{tabular}

dan kakao. Walaupun hasil ini merupakan suatu penelitian awal, tetapi dapat disimpulkan sawit memiliki keanekaragaman katak yang rendah, dibandingkan dengan keanekaragaman di hutan sekunder.

Tabel 7 dan Tabel 8 menunjukkan bahwa dalam penelitian ini tidak ada perbedaan jumlah spesies pada sawit dengan umur tanam yang berbeda, walaupun waktu tanam sangat jauh berbeda, yakni 38 tahun, 30 tahun dan 6 tahun. Banyak hal yang dapat dibahas dari hasil ini, antara lain sejak perubahan fungsi hutan spesies asli tidak dapat kembali ke habitat sawit walaupun sudah berumur 30-38 tahun. Dapat juga diartikan perubahan fungsi hutan ke sawit memberikan dampak yang pernamen terhadap keragaman katak. Perlu penelitian lanjut untuk melihat faktor-faktor yang mempengaruhi hal ini. Perbedaan antara sawit berbeda umur tanam adalah jumlah individu secara signifikan (Tabel 7 dan Tabel 8). Gambar 10 menunjukkan bahwa Indek Keragaman Jenis ( $\mathrm{H}^{\prime}$ ) tidak banyak berbeda antara perkebunan sawit.

Gambar 10 menunjukkan perbandingkan Indeks Keragaman Katak pada sawit dengan umur tanam yang berbeda. Hasil t-test menunjukkan tidak ada perbedaan nyata (significant) antara sawit berbeda umur tanam.

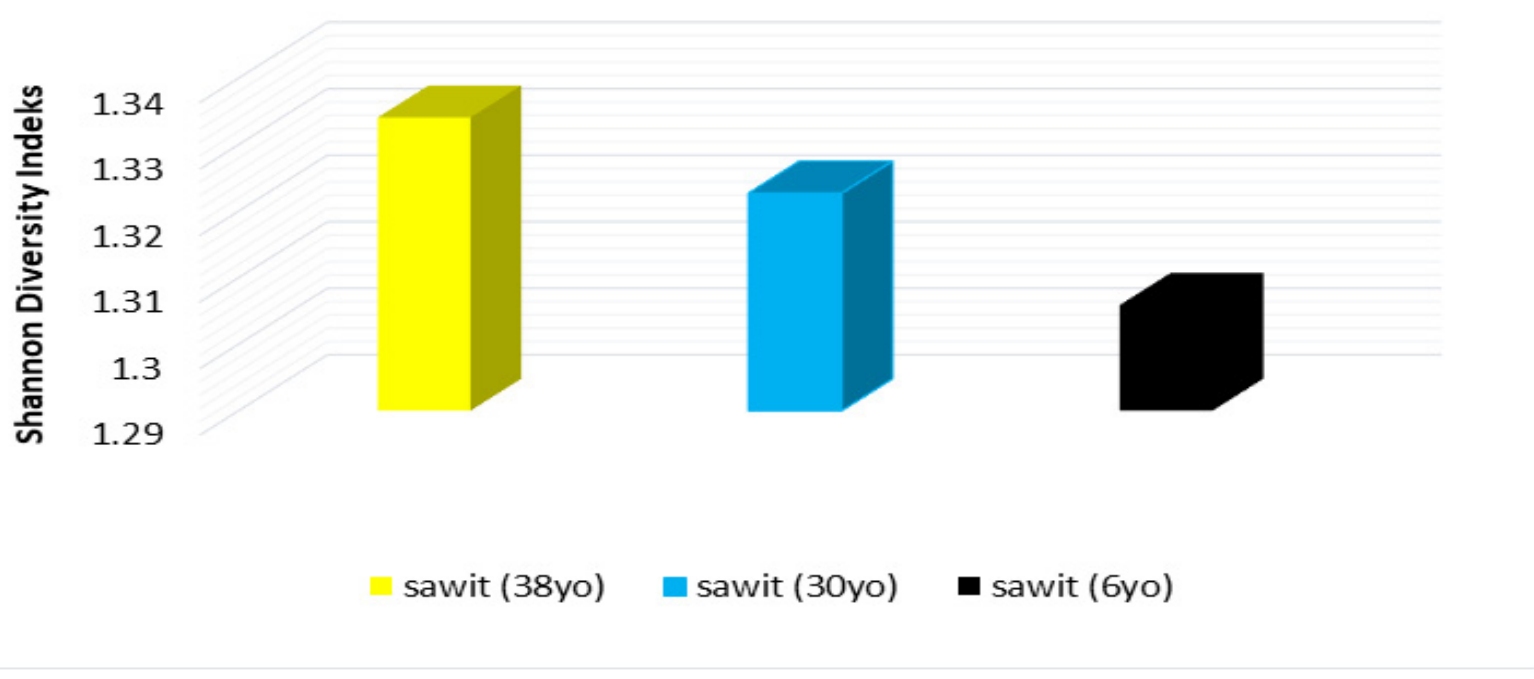

Gambar 10. Perbandingan Indeks Keragamanan Jenis Katak pada Perkebunan Sawit Berbeda Umur Tanam 
Tabel 8.

Hasil Anova Perbandingan Jumlah Individu Katak pada Lokasi Penelitian

\begin{tabular}{ccccccc}
\hline Source of Variation & SS & df & MS & F & P-value & F crit \\
\hline Between Groups & 293,1667 & 2 & 146,5833 & $\mathbf{4 , 5 5 6 9 9 5}$ & 0,042956 & $\mathbf{4 , 2 5 6 4 9 5}$ \\
\hline Within Groups & 289,5 & 9 & 32,16667 & & \\
\hline Total & 582,6667 & 11 & & & \\
\hline
\end{tabular}

Uji Anova atas jumlah individu katak pada perkebunan sawit dengan beda umur tanam menunjukkan bahwa ada perbedaan yang signifikan antara sawit dengan umur tanam yang lama dan yang baru.

Hasil ini menunjukkan bahwa perubahan hutan ke perkebunan sawit berdampak negatif terhadap keanekaragaman katak. Misalnya, dari 6 spesies katak pada hutan sekunder, tidak tercatat pada tiga lokasi perkebunan sawit. Hanya Cornufer papuensis yang dapat diamati di hutan sekunder dan lokasi perkebunan. Spesies ini diketahui memiliki daerah distribusi yang luas dari dataran rendah sampai ke pegunungan dan dapat hidup pada habitat yang sudah rusak (Zweifel et al., 1969). Sebaliknya spesies Papurana arfaki dan Litoria infrafrenata yang terkenal memiliki distribusi yang luas di seluruh Pulau New Guinea dan Indonesia $(L$. infrafrenata) dan termasuk spesies yang umum (common species) tidak berhasil diamati pada ketiga lokasi perkebunan selama penelitian ini.

\section{H. Penelitian Dampak Perkebunan Sawit terhadap Keanekaragaman Hayati}

Beberapa penelitian lain mengenai dampak perkebunan kelapa sawit terhadap keanekaragaman hayati menunjukkan hasil yang sama bahwa perkebunan kepala sawit berdampak negatif terhadap keanekaragaman. Misalnya, Kwatrina dkk (2019) melakukan penelitian pada dampak perkebunaan sawit terhadap keanekargamanan herpetofauna di beberapa perkebunan sawit dengan usia tanam yang berbeda di Kalimantan Tengah menyimpulkan bahwa keragamanan hayati rendah di perkebunan sawit dibandingan hutan sekunder sekitar perkebunan. Namun penelitian mencatat bahwa ada perbedaan jumlah spesies perkebunan sawit berusia 5 tahun, berusia 11 tahun dan berusia 20 tahun. Perkebunan sawit berusia 20 tahun memiliki lebih banyak spesies. Ini sedikit berbeda dengan hasil penelitian ini, dimana tidak ada perbedaan antara perkebunan sawit walaupun berbeda usia tanam sekitar 22 tahun. Penelitian lainnya terhadap keragamanan tumbuhan pada beberapa perkebunan sawit Kabupaten Riau menunjukkan ada kehilangan spesies antara 60-70\% di perkebunan sawit (Nahlunnisa et al., 2017).

Penelitian keragamanan arthopoda pada beberapa perkebunan sawit di Dharmasraya, Sumatera Barat (Heriza et al., 2017) memberikan nilai Indeks Shannon Diversiti H': 0,33 untuk keragamanan arthopoda di perkebunan sawit. Walaupun dalam penelitian ini hanya pada tingkat famili dan tidak membandingkan hutan atau habitat lainnya, nilai $\mathrm{H}^{\prime}: 0,33$ menunjukkan tingkat keragaman yang sangat rendah. Penelitian dampak perkebunan sawit terhadap keaneragaman burung, Kalimantan Tengah, walaupun tidak memberikan penjelasan yang tegas tentang hasilnya, tetapi menyimpulkan bahwa keragamanan spesies burung di perkebunan sawit lebih rendah dari keragamanan burung di hutan sekitarnya (Santosa et al., 2018).

Penelitian ini hanya melihat dampak perubahan hutan terhadap keanekaragaman katak. Masih diperlukan lagi penelitian lanjutan untuk melihat faktor-faktor yang menyebabkan tidak adanya spesies asli Papua di perkebunan kakao dan sawit. Suatu faktor perbedaan yang sangat menyolok dari tiga lokasi penelitian ini adalah adanya tumbuhan atau vegetasi bawah pada hutan sekunder. Hampir semua perkebunan dan kakao, walaupun telah ditanam hampir 40 tahun lalu dan tidak begitu terurus dengan baik, tetapi pertumbuhan vegetasi masih terbatas. Vegetasi 
pada sawit dan kakao, umumnya didominasi oleh beberapa jenis saja (Ficus sp. dan polongan dari Fabaceae). Faktor lingkungan lainnya yang diduga kuat berkontribusi pada perubahan keanekaragaman katak pada lokasi adalah suhu dan kelembaban katak, ataupun kimia tanah (akibat proses pemupukan atau pengontrolan hama). Dianggap perlu memperluas penelitian lanjutan untuk memastikan dampak perkebunan sawit dan kakao terhadap keragaman spesies katak dan spesies lainnya. Misalnya, memperbanyak transek di hutan, sawit dan kakao dan habitat lainnya yang ada di Prafi, termasuk hutan yang masih baik, bekas kebun atau kebun baru agar dapat mengambil suatu kesimpulan yang tegas tentang dampak perubahan hutan alam, terutama untuk perkebunan sawit dan kakao, terhadap keanekaragaman katak.

\section{Deskripsi Katak}

Hasil penelitian ini berhasil mencatat 10 spesies dari 6 family yang dapat dilihat pada tabel 9 disertai gambar spesies. Setiap spesies memiliki morfologi yang berbeda. Deskripsi katak dilakukan dengan melihat beberapa bagian organ tubuh dari katak diantaranya yaitu bentuk kepala, warna punggung, kulit, kaki, panjang SVL serta TL. Deskripsi katak diidentifikasi berdasarkan foto atau gambar yang diperoleh saat proses pengambilan data di lapangan dan juga dari hasil spesimen katak.

Tabel 9.

Deskripsi Katak

\begin{tabular}{|c|l}
\hline Spesies & \multicolumn{1}{c}{ Deskripsi } \\
\hline Duttaphrynus melanostictus & $\begin{array}{l}\text { Duttaphrynus melanostictus termasuk dalam family } \\
\text { Bufonidae. Spesies ini ditemukan di Kampung Uyehegbrik } \\
\text { pada habiat hutan dengan panjang tubuh dari moncong } \\
\text { hingga kloaka (SVL) mencapai } 56,85 \mathrm{~mm} \text { sedangkan panjang } \\
\text { tibia (TL) mencapai } 27,49 \mathrm{~mm} \text {. Bentuk kepala ramping dengan } \\
\text { nose tidak meruncing. Warna dorsal hijau dan bercorak } \\
\text { warna coklat tidak beraturan, memiliki garis ditengah dorsal } \\
\text { dari ujung moncong hingga kloaka. Tekstur kulit kasar dan } \\
\text { berbintik-bitik, jari depan dan belakang memiliki selaput yang } \\
\text { pendek. }\end{array}$ \\
\hline
\end{tabular}

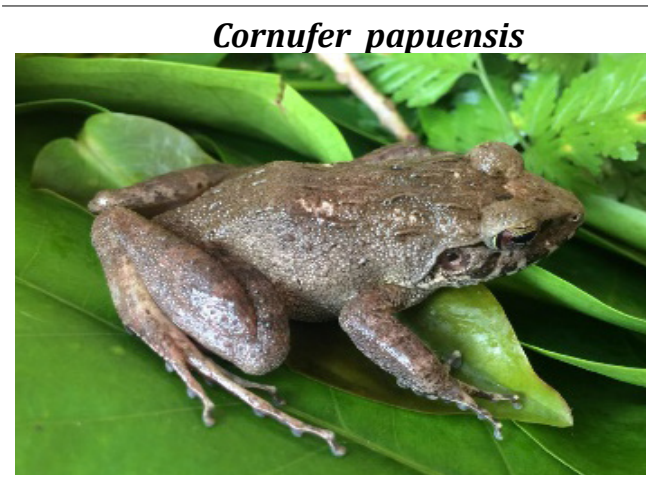

Cornufer papuensis termasuk dalam family Ceratobatrachidae. Spesies ini ditemukan di Kampung Uyehegbrik terdapat pada habitat Hutan. Warna dorsal coklat muda dan bercorak warna coklat gelap tidak beraturan. Panjang tubuh dari moncong hingga kloaka (SVL) mencapai 52,48 mm sedangkan panjang tibia (TL) mencapai $28,70 \mathrm{~mm}$. Kaki depan tidak memiliki selaput berbeda dengan kaki belakang yang memiliki selaput pendek, pada kaki terdapat garis coklat tua, tekstur kulit kasar. Spesies ini dapat dijumpai di area dataran rendah.

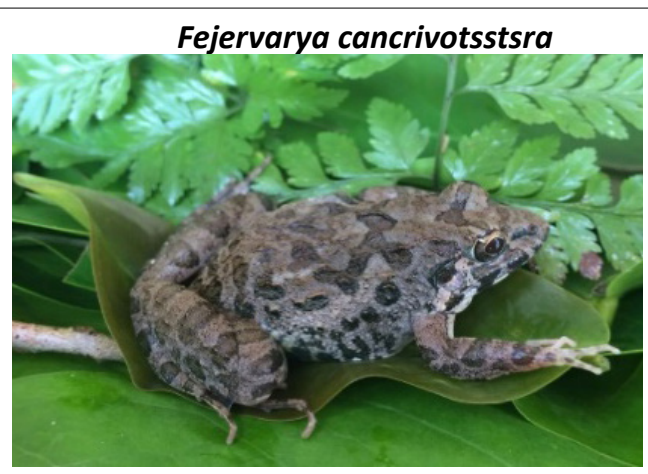

Fejervarya crancivora termasuk dalam family Dicroglossidae. Warna dorsal hitam dan bercorak warna coklat gelap tidak beraturan. Panjang tubuh dari moncong hingga kloaka (SVL) mencapai 52,48 $\mathrm{mm}$ sedangkan panjang tibia ( $T L$ ) mencapai $28,70 \mathrm{~mm}$. Pada kaki terdapat garis coklat tua, tekstur kulit kasar. Spesies ini dapat dijumpai di area dataran rendah. 


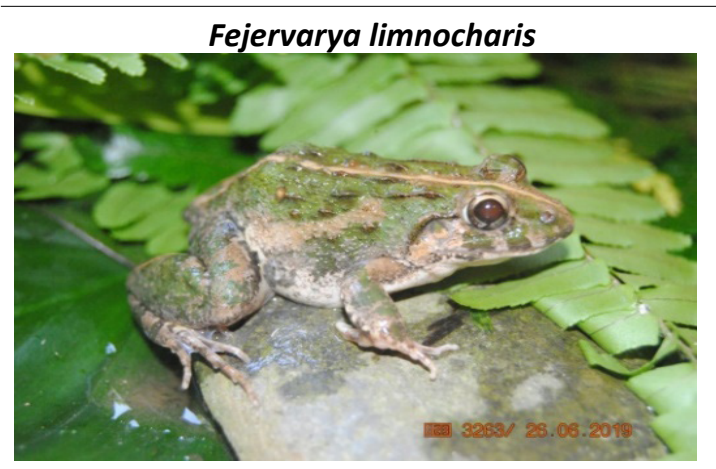

Fejervarya limnocharis merupakan spesies yang termasuk dalam family Dicroglossidae. Spesies ini ditemukan di Kampung Uyehegbrik pada habitat hutan. Panjang tubuh dari moncong hingga kloaka (SVL) mencapai 45,83 mm sedangkan panjang tibua (TL) mencapai 23,71 mm. Dorsal berwarna coklat tidak beraturan dan memiliki garis ditengan dari moncong hingga kloaka kekuningan . Tekstur kulit kasar, jari kaki depan dan belakang meliki selaput pendek, pada kaki depan dan belakang terdapat garis coklat.

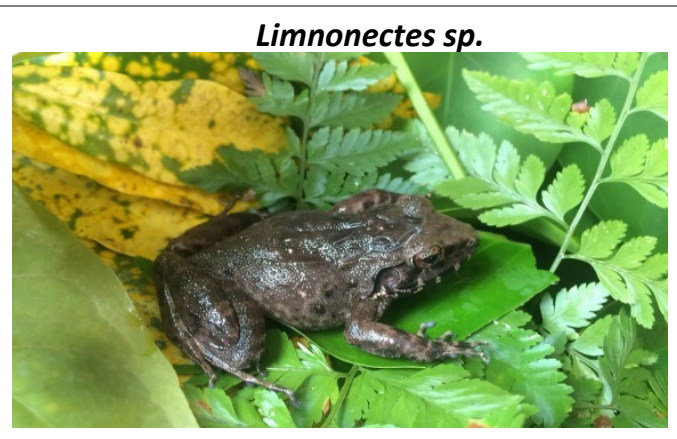

Limnonectes sp. termasuk dalam family Ceratobatrachidae. Spesies ini ditemukan di Kampung Aimasi terdapat pada habitat Kakao. Warna dorsal coklat muda dan bercorak warna coklat gelap tidak beraturan. Panjang tubuh dari moncong hingga kloaka (SVL) mencapai 52,48 $\mathrm{mm}$ sedangkan panjang tibia (TL) mencapai $28,70 \mathrm{~mm}$. Kaki depan tidak memiliki selaput berbeda dengan kaki belakang yang memiliki selaput pendek, pada kaki terdapat garis coklat tua, tekstur kulit kasar. Spesies ini dapat dijumpai di area dataran rendah.

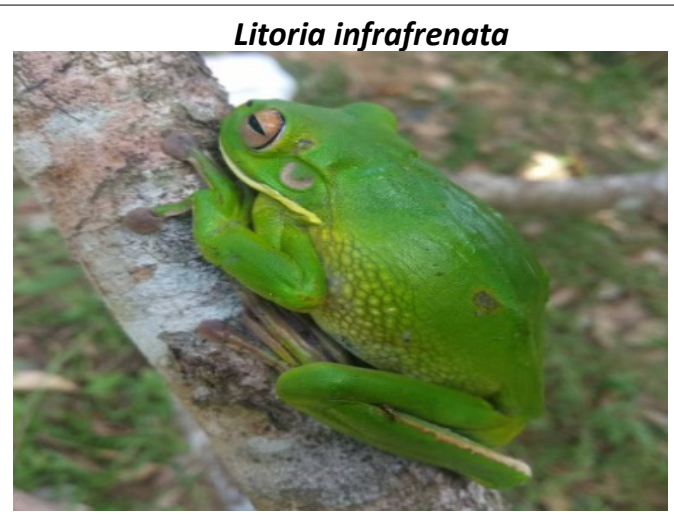

Litoria infrafrenata termasuk dalam family Hilydae. Spesies Litoria Infrafrenata atau biasa dikenal dengan sebutan katak pohon tersebar luas di Indonesia hingga Autralia (Iskandar, 2000). Litoria infrafrenata sangat umum dijumpai pada semua habitat. Bentuk kepala besar degan nose yang bundar. Dorsal berwarna hijau. Panjang tubuh dari moncong hingga kloaka (SVL) mencapai 102,99 mm sedangkan panjang tibia (TL) mencapai 53, $66 \mathrm{~mm}$. kaki depan dan belakang berselaput pendek, tekstur kulit licin. Spesies ini ditemukan di Kampung Uyehegbrik pada habitat Hutan dengan ketinggian berkisar 200-an m dpl.

Cophixalus sp.

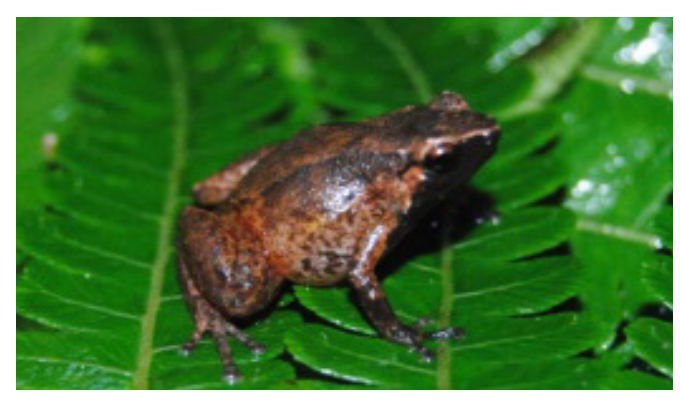

Callulops sp.

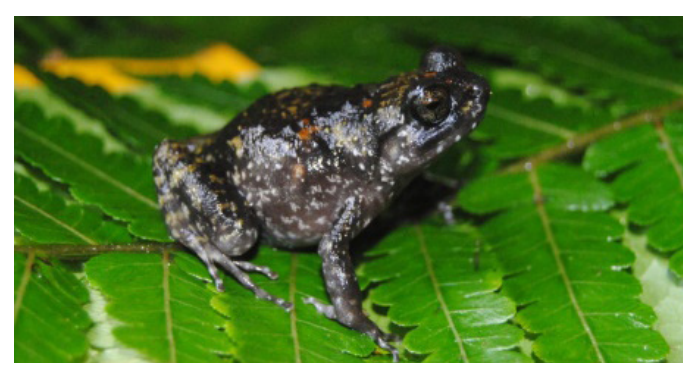

Cophixalus sp. termasuk dalam family Microhylidae. Katak berukuran kecil dan ramping. Panjang tubuh dari moncong hingga kloaka (SVL) mencapai 18,23 mm sedangkan panjang tibia (TL) mencapai 9,17 mm. Spesies ini ditemukan di Kampung Uyehegbrik pada habitat hutan. Warna dorsal coklat tua dengan bentuk kepala yang kecil dan nose tidak meruncing, tekstur kulit licin, jari kaki depan dan belakang tidak memiliki selaput dan berukuran kecil.

Callulops sp. merupakan spesies yang termasuk dalam family Microhylidae. Spesies ini ditemukan di Kampung Uyehegbrik pada habitat akuatik. Kepala kecil dan lebar dengan nose yang tidak meruncing. Tektur kulit licin, warna dorsal hitam bercorak orange dan putih tidak beraturan. Jari kaki depan dan belakang tidak memiliki selaput, pada kaki terdapat garis atau strep warna putih gelap. 


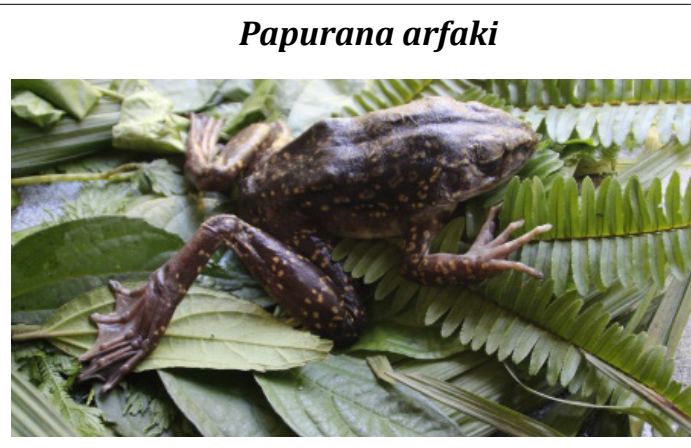

Papurana arfaki merupakan spesies yang termasuk dalam family Ranidae. Panjang tubuh dari moncong hingga kloaka (SVL) mencapai 94,23 mm sedangkan panjang tibia (TL) mencapai 51,73 mm. Bentuk kepala lebar dengan nose yang tidak meruncing. Dorsal berwarna hitam dan bercorak warna putih kecoklatan dengan tidak beraturan, tekstur kulit licin, jari kaki belakang memiiki selaput yang penuh berbeda dengan jari kaki depan yang tidak memiliki selaput. Spesies yang ditemukan berjenis kelamin jantan.

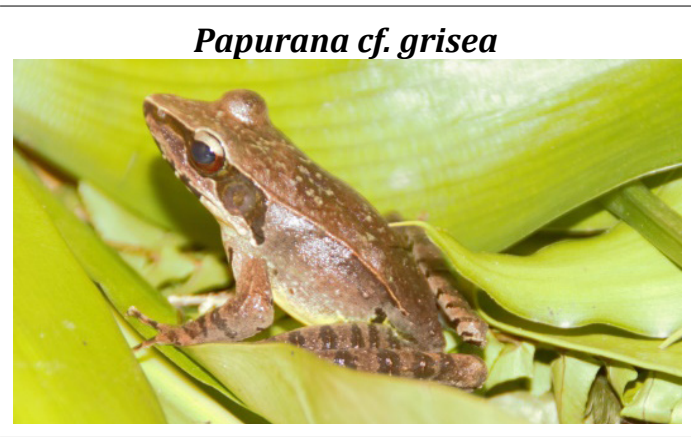

Papurana cf. grisea termasuk dalam family Ranidae. Spesies ini ditemukan di Kampung Uyehegbrik pada habitat hutan. Pajang tubuh dari moncong hingga kloaka (SVL) mencapai 97,7 mm sedangkan panjang tibia (TL) 64,87 mm. Bentuk kepala meruncing, kaki depan dan belakang memiliki garis yang berwarna coklat tua, jari depan dan belakang tidak memiliki selaput. Warna dorsal coklat terdapat corak putih dantekstur kulit licin.

\section{KESIMPULAN}

Penelitian ini berhasil mencatat 10 spesies katak dari 6 famili. Perubahan fungsi hutan telah berdampak negatif terhadap keanekaragaman katak. Ada penurunan jumlah spesies dan indek keanekaragaman jenis yang nyata pada lokasi perkebunan dalam penelitian ini. Spesies-spesies seperti Callulops sp. Cophixalus sp. Papurana arfaki dan Papurana cf. grisea yang tidak dijumpai di kawasan non hutan (sawit dan kakao). Dari 6 spesies katak asli Papua, hanya 1 spesies saja yang berhasil diamati di perkebunan kakao yang berjarak antara 4-6 km dari hutan sekunder ini. Jika terus terjadi perubahan fungsi hutan, maka spesies katak Papua akan terancam punah atau tergantikan dengan spesies yang mampu beradaptasi, terutama spesies yang dintroduksi, seperti Duttaphrynus melanostictus, Fejervarya cancrivora dan Fejervarya limnocharis. Kehadiran D. melanostictus yang berhasil diamati di setiap lokasi penelitian sangat mengkhawatirkan.

Adanya spesies introduksi Fejervarya limnocharis perlu diteliti lebih lanjut, karena selama ini spesies hanya terdapat di daratan Asia Tenggara sampai Pulau Flores. Selain untuk memastikan status spesies dan penyebarannya, perlu melihat bagaimana kompetisi dengan spesies lokal (baik dalam makan maupun pemanfaatan habitat). Walaupun hasil penelitian ini menunjukkan dampak negatif perkebunan sawit dan kakao terhadap spesies katak asli Papua (tidak ada di lokasi perkebunan sawit dan kakao), tetapi belum dapat menjelaskan faktor-faktor utama penyebab hal ini. Perlu penelitian untuk melihat apakah karena faktor fisik (suhu dan kelembaban tanah) atau faktor biologis (habitat, persaingan dengan spesies introduksi), maupun fakor kimia (pemakaian pestisida dan pupuk di lahan perkebunan).

\section{UCAPAN TERIMA KASIH}

Kami menyampaikan terima kasih kepada masyarakat di Distrik Prafi yang telah dan membantu penelitian ini. Terima kasih juga kepada Steve Richards yang telah membantu dalam identifikasi. Terima kasih juga kepada para reviewer yang telah merevisi naskah ini dan kepada Badan Penelitian dan Pengembangan Daerah Provinsi Papua Barat atas kesempatan penerbitan artikel ini.

\section{Daftar Pustaka}

Apsyari, A. N. (2020). Keanekaragaman Katak Dari Berbagai Habitat di Distrik Prafi Manokwari. Universitas Papua.

Conservation, I. (2020). Model Prediksi 
Perubahan Tutupan Hutan Provinsi Papua Barat.

Crump, M.L., \&Jr., N.J.S. (1994). Visual Encounter Surveys. Chapter 2 in Measuring dan Monitoring Biological Diversity Standard Methods for Ampibians. Smithsonian Institution Press.

Gardener, M. (2017). Statistics for Ecologists Using $R$ and Excel; Data Collection, Exploration, Analysis and Presentation (2nd Edition). Pelagic Publishing.

Hartshorn, G. S. (2021). Understanding Tropical Forests. BioScience, 56(3), 264-265. https://doi.org/10.1093/biosci/biab062

Heriza, S., Noferta, A., \& Aligandi, N. (2017). Keanekaragaman Artropoda pada Perkebunan Kelapa Sawit Rakyat di Kabupaten Dharmasraya, Provinsi Sumatera Barat. Jurnal Perlindungan Tanaman Indonesia, 21(1), 47-50. https:// doi.org/10.22146/jpti.18420

Heyer, W. R., Donnelly, M. A., \& McDiarmid, R. W. (1994). Measuring and Monitoring Biological Diversity: Standard Methods for Amphibians. Smithsonian Institution Press.

Kartikasari, S., Marshall, A., \& Beehler, B. M. (2012). Ekologi Papua. Yayasan Obor Indonesia.

Krebs, C. J. (1999). Ecological Methodology (2nd, berilustrasi ed.). Benjamin/Cummings.

Kwatrina, R. T., Santosa, Y., \& Maulana, P. (2019). Keanekaragaman Spesies Herpetofauna pada Berbagai Tipe Tutupan Lahan di Lansekap Perkebunan Sawit: Studi Kasus di PT. BLP Central Borneo. Journal of Natural Resources and Environmental
Management, 9(2), 304-313. https://doi. org/10.29244/jpsl.9.2.304-313

Magurran, A. E. (2013). Ecological Diversity and Its Measurement. In Berilustrasi (Ed.), Springer Science \& Business Media. Springer Science \& Business Media.

Menzies, J. (2006). The Frogs of New Guinea and the Solomon Islands (col illus, Vol. 48). Pensoft Publishers.

Nahlunnisa, H., Santosa, Y., \& Zuhud, E. A. (2017). Dampak Perkebunan Kelapa Sawit Terhadap Keanekaragaman Spesies Tumbuhan Tropika (Studi Kasus: Provinsi Riau). Wahana Forestra: Jurnal Kehutanan, 12(1), 76-88. https://doi.org/10.31849/ forestra.v12i1.204

Richards, S. J., Iskandar, D. T., \& Tjaturadi, B. (2002). Amphibians and reptiles of the Dabra Area, Mamberamo River Basin, Papua, Indonesia. Conservation International RAP Bull, 25(9), 69-79.

Santosa, Y., Sugiharti, W., \& Erniwati. (2018). The variation of bird diversity in different land cover at oil palm plantation: case study at Asm Oil Palm Estate in Central Kalimantan, Indonesia. E3S Web of Conferences, 52, 1-8. https://doi. org/10.1051/e3sconf/20185200051

Stebbins, R. C., \& Cohen, N. W. (1997). A Natural History of Amphibians. Princeton University Press.

Zweifel, R. G., Gilliard, E. T., \& Somadikarta, S. (1969). Frogs of the Genus Platymantis (Ranidae) in New Guinea, with the Description of a New Species. New York, N.Y. : American Museum of Natural History. 